\title{
"Iedutech" Mobile Application Development for Information Technology Subjects in Education among TVET Students
}

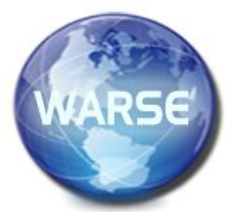

\author{
Ahmad, F. ${ }^{1}$, Hamzah, N. ${ }^{2}$, Wan Hassan, W.A.S. ${ }^{3}$, Mansor, A.H. ${ }^{4}$ \\ ${ }^{1,2,3}$ Faculty of Technical and Vocational Education, Universiti Tun Hussein Onn Malaysia \\ ${ }^{4}$ School of Education, Universiti Teknologi Malaysia \\ muhdfazrulhelmi@gmail.com ${ }^{1}$
}

\section{ABSTRACT}

Mobile application development is a complex process, it is a heavy responsibility for researcher to produce a mobile application that is developed to meet the quality and achieve its objectives. The use of mobile technology is a way of learning that fits with today's educational needs. This study to develop the Iedutech Mobile Application to facilitate the Teaching and Learning (T\&L) process in the classroom for Information Technology in Educational subjects related to Network and Communication topics. Researcher use the ADDIE Model in developing the Iedutech application to provide a systematic work guide in which the phases are (i) Analysis phase, (ii) Design phase, (iii) Development phase, (iv) Implementation phase and (v) Evaluation phase. It also uses Adobe Flash CS6 as a platform for developing the Iedutech application. The respondents involved in the development of this Iedutech applications consisted of 25 Bachelor of Vocational Education (ISMPV) students at Faculty of Technical and Vocational Education (FPTV), UTHM who took the subject of BBD10803 Information Technology in Education. The evaluation of this application was carried out using questionnaires. It was expected that the Iedutech application would be developed for the benefit of users, especially the TVET students and lecturers.

Key words: Mobile Application, Information Technology in Education, Teaching and Learning (T\&L)

\section{INTRODUCTION}

Learning is an important process for acquiring knowledge, practicing training, developing skills and harnessing the inner talent and potential for success and excellence [1]. Learning style is an action taken by a student based on his or her own learning experiences [2]. Therefore, in the context of educational psychology, learning style refers to the way one focuses and acts to the process of acquiring new information, knowledge or experience. An engaging learning style can stimulate students' interest in learning. With the development of information and communication technologies, m-learning has emerged as a paradigm of modern education [3].
Through the use of m-learning methods, the learning process is no longer focused on a single platform or limited to a classroom but m-learning is more just-in-time, just-in-case, on-move and on-demand [4]. Generally, the use of mobile applications is one of the alternative techniques to existing white-board teaching and learning methods and pen markers or traditional methods using blackboard and chalkboard. This has shown that the use of mobile devices makes learning easier anytime and anywhere than the use of easily damaged and non-durable notebooks [5]. However, some lecturers face problems when using teaching aids in addition to traditional methods. This makes the students less interested in learning and directly become bored of the teacher-taught teaching and learning (T\&L) method. The subject of information technology in education was selected by researchers in developing Iedutech applications.

\section{PROBLEM STATEMENT}

There are some problems that occur during the $\mathrm{T} \& \mathrm{~L}$ process in the classroom. No variation in learning is provided to students during the T\&L process. Furthermore, teachers' fail to identify appropriate learning styles for each student in the classroom and at the same time less exposure is provided in the use of information technology such as m-learning in the teaching process. Some teachers are having trouble using the latest teaching aids other than traditional methods.

Although this problem can be completely solved by using the android application in analyzing students' learning style, educators should play a role in guiding students in recognizing their own learning style [6]. This is supported by [7] where educators are individuals who play important roles in produce outstanding and high quality students.

The objectives of the research are as follows:

i. To design Iedutech Mobile Applications for Information Technology in educational subjects.

ii. To develop Iedutech Mobile Application to access the android platform-based design (ADDIE).

iii. To evaluate the user's usability of the Iedutech Mobile Application for Information Technology in educational subjects. 


\section{M-LEARNING}

More and more people are owning and using mobile devices in the educational world. The use of mobile devices in the teaching and learning process is known as m-learning or $\mathrm{m}$-learning [8]. The presence of m-learning is a complement to $\mathrm{T} \& \mathrm{~L}$ for students to re-learn the less-powerful materials anywhere and anytime. This will certainly provide a different experience in the learning process for students. This is supported by [9] where mobile learning can enhance the learning process by using technology at the fingertips and stimulating students to integrate independent learning into their education. In addition, according to [10], the application of this learning tool enables students to understand the material in a short time and easy way.

\section{RESEARCH METHODOLOGY}

The study conducted was descriptive, whereby the data analyzed were obtained from the questionnaire distributed to the respondents. This method was used due to its convinience to collect effective, economical and practical data which can save cost, energy and time [11].

\subsection{Sample and Population}

The targeted population for this study were Bachelor of Vocational Education (ISMPV) students at the Faculty of Technical and Vocational Education (FPTV), UTHM who took the subject of BBD10803 Information Technology in Education. The researchers selected a sample who are taking the subject of BBD10803 Information Technology in Education in the first semester of 2019/2020 session.

\subsection{Instrument of Study}

The questionnaire using a Likert scale was developed by the researcher to identify and collect information. The questionnaire form is a form of questionnaire application using android applications for users. The questionnaire contained 30 item software-related developed in the Iedutech application. The items in question included multimedia elements that were relevant to the material being developed. The items in the questionnaire were divided into five (5) sections, as in Table 1 below.

Table 1. Respondents Questionnaire

\begin{tabular}{|c|l|c|}
\hline Section & \multicolumn{1}{|c|}{ Aspect } & $\begin{array}{c}\text { Number of } \\
\text { question }\end{array}$ \\
\hline A & Respondent's information & 4 \\
\hline B & Content design & 10 \\
\hline C & Interaction design & 10 \\
\hline D & Interface design & 10 \\
\hline E & Comments and suggestion & 1 \\
\hline
\end{tabular}

\subsection{Application Development}

In developing the Iedutech application, the researcher chose the ADDIE Model (Rossett, 1987). This is because, according to [12], these models are among the instructional design models that are often the basis of other instructional design models. In addition, according to [13], the ADDIE model is one of the systematic models of teaching design in producing effective and user-friendly computerized learning materials. Developers use the ADDIE Model in developing android applications to provide a systematic working guide. There are five (5) phases using the ADDIE Model namely (i) the analysis phase, (ii) the design phase, (iii) the development phase, (iv) implementation phase and (v) the evaluation phase. Figure 1 shows the process for designing Iedutech applications based on ADDIE Theory.

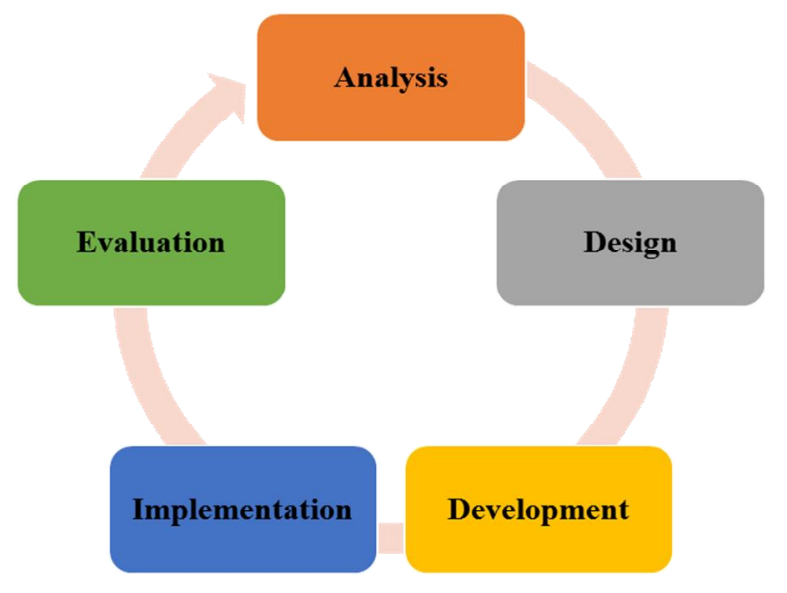

Figure 1: The Process Of Designing Iedutech Applications Based on ADDIE Theory. [14]

The analysis phase was the initial phase before the android application was developed. This phase involves several steps starting with target analysis, content selection analysis, delivery strategy selection analysis, needs analysis and media and material selection analysis [12]. Next, the design phase is for activities such as the construction of flow charts, navigation structures and storyboards. For the development phase, application software will be developed step by step to ensure that the content meets the syllabus requirements. This phase will also go through a testing process to ensure that there is no technical and content errors or any other weaknesses that need be corrected by the developer. This is to ensure that the android application developed works well, meets the goals of production and quality and meets the user needs.

The implementation phase is the most important phase in the development of an application as it is the phase that determines whether the development of this android application is objective. The evaluation phase is the last phase performed on the ADDIE model. There are two types of assessments which are formative and summative. The result of formative assessment is to streamline the implementation phase of an application, gather feedback and identify problems with the application being developed. Figure 2,3,4,5 and 6 contains the partial content of the Iedutech application. 


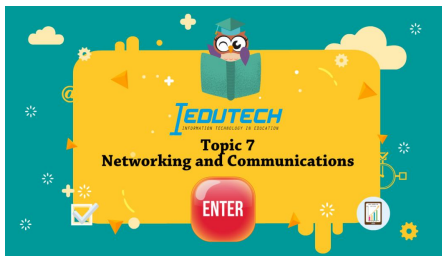

(a) Montage

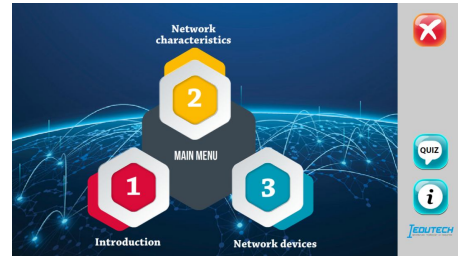

(b) Menu Option

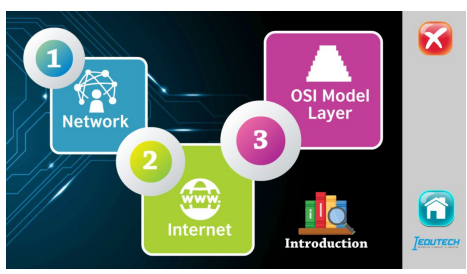

(c) Sub Menu

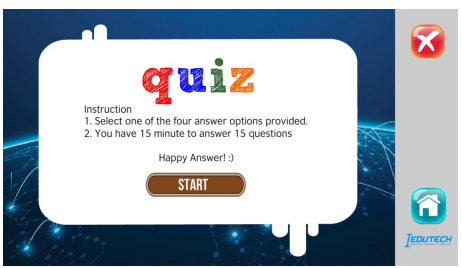

(d) Quiz

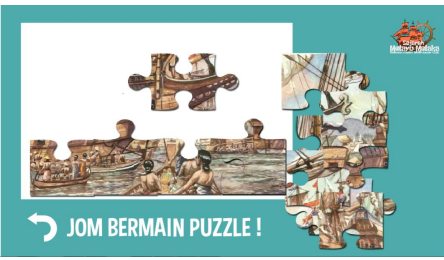

(e) Puzzles

Figure 2: Partially Content the Iedutech Mobile Application

\section{DATA ANALYSIS AND DISCUSSION}

Descriptive statistical methods were used by researchers to describe the information obtained from the respondents and processed, analyzed and evaluated using the mean value and interpretation. The data obtained were analyzed using the Statistical Package for the Social Sciences (SPSS) version 22.0 software. Summative assessment were conducted using the four-choice Likert scale, which are Strongly Agree (SA), Agree (A), Disagree (D) and Strongly Disagree (SD). Table 2 shows the Likert scale size.

Table 2: Likert Scale Size

\begin{tabular}{|c|c|}
\hline Tendency & Score \\
\hline Strongly Disagree (SD) & 1 \\
\hline Disagree (D) & 2 \\
\hline Agree (A) & 3 \\
\hline Strongly Agree (SA) & 4 \\
\hline
\end{tabular}

\subsection{Content Design Analysis}

The student-user evaluation was performed to evaluate the usability of the Iedutech mobile application that was developed. User evaluation of content is done to determine the accuracy of the content included in this Iedutech application. The data shows the content analysis evaluation ( mean $=4.09$, sd $=0.64$ ). This shows that overall, the students agree with the content contained in the developed Iedutech mobile application. This is evidenced by the highest mean value (mean $=4.26$, sd $=0.60$ ) that says, 'this android application encourages me to think creatively and critically'. The use of mobile applications will help one to generate ideas and discover new specimens that can help one to think of new ideas and it may be a good idea [15].

In addition, learning to use this app is important because students' logical thinking is about quality in terms of style, inspiration and critical and creative thinking, in line with what is recommended by [16]. Table 3 shows content design analysis of users.

Table 3: Content Design Analysis of Users

\begin{tabular}{|c|c|c|c|}
\hline No. & Details & Mean & $\begin{array}{c}\text { Std. } \\
\text { Deviation }\end{array}$ \\
\hline 1. & $\begin{array}{l}\text { This Iedutech application } \\
\text { helped me to study the topic of } \\
\text { the network visually. }\end{array}$ & 4.29 & 0.72 \\
\hline 2. & $\begin{array}{l}\text { This Iedutech application can } \\
\text { help me remember the types of } \\
\text { networks. }\end{array}$ & 4.00 & 0.85 \\
\hline 3. & $\begin{array}{l}\text { The content delivery is of } \\
\text { interest to me. }\end{array}$ & 4.15 & 0.78 \\
\hline 4. & $\begin{array}{l}\text { I can easily understand the } \\
\text { topics taught using this } \\
\text { Iedutech application. }\end{array}$ & 4.15 & 0.78 \\
\hline 5. & $\begin{array}{l}\text { The videos provided help me } \\
\text { improve my understanding. }\end{array}$ & 4.00 & 0.80 \\
\hline 6. & $\begin{array}{l}\text { The graphic info provided can } \\
\text { help improve my } \\
\text { understanding. }\end{array}$ & 4.11 & 0.71 \\
\hline 7. & $\begin{array}{l}\text { This Iedutech application } \\
\text { encourages me to think } \\
\text { creatively and critically. }\end{array}$ & 4.26 & 0.60 \\
\hline 8. & $\begin{array}{l}\text { This Iedutech application has } \\
\text { helped me to remember the } \\
\text { topic of network and } \\
\text { communication for a long } \\
\text { time. }\end{array}$ & 3.88 & 0.76 \\
\hline 9. & $\begin{array}{l}\text { There are enough quizzes and } \\
\text { exercises. }\end{array}$ & 4.15 & 0.73 \\
\hline 10. & $\begin{array}{l}\text { After using this Iedutech } \\
\text { application, i was able to } \\
\text { answer the test questions with } \\
\text { better performance. }\end{array}$ & 4.07 & 0.79 \\
\hline \multicolumn{2}{|c|}{$\begin{array}{c}\text { Total Average } \\
\end{array}$} & 4.09 & 0.64 \\
\hline
\end{tabular}




\subsection{Interaction Design Analysis}

The data obtained is the result of the user survey questionnaire in the interaction design section. The selected users have rated the Iedutech mobile application learning application with the item they have provided. There are ten (10) questions and this interrelated design section that focused on the navigation buttons, menus, icons, colors used in Iedutech Mobile Application Development. The interaction design evaluation (mean $=4.17, \mathrm{sd}=0.67$ ) showed that the respondents agreed with the interaction design found in the Iedutech mobile application. The item "color usage in this android app is very good to see" showed a high mean value in the design evaluation of this interaction $($ mean $=4.23$, sd $=0.76)$.

This finding is in line with the findings of [17], who stated that elements of graphic design, text, color and sound enabled students to pay close attention to learning as well as to their syllabus that could meet students' tastes. In addition, the choice of color was also relevant to human psychology because color played a role in human perception [18]. Additionally, items (mean $=4.11$, sd $=0.76$ ) of "icons and buttons used were appropriate" provided low response by respondents. This finding explained that icons needed to be positioned consistently so that users did not have to guess what to do next or use the mouse to click in the hope that they could find a way to proceed [19]. Table 4 shows the interaction design analysis of users.

Table 4: Interaction Design Analysis of Users

\begin{tabular}{|c|l|c|c|}
\hline No. & \multicolumn{1}{|c|}{ Details } & Mean & $\begin{array}{c}\text { Std. } \\
\text { Deviation }\end{array}$ \\
\hline 1. & $\begin{array}{l}\text { I can control the speed of the } \\
\text { content presentation in this } \\
\text { Iedutech application. }\end{array}$ & 4.15 & 0.78 \\
\hline 2. & $\begin{array}{l}\text { The presentation of the content } \\
\text { in this Iedutech application is } \\
\text { subject to topic. }\end{array}$ & 4.15 & 0.78 \\
\hline 3. & $\begin{array}{l}\text { This Iedutech application is } \\
\text { divided into other related } \\
\text { sections. }\end{array}$ & 4.23 & 0.71 \\
\hline 4. & $\begin{array}{l}\text { The content of the lessons is } \\
\text { easy to follow. }\end{array}$ & 4.19 & 0.69 \\
\hline 5. & $\begin{array}{l}\text { The menu view of this } \\
\text { Iedutech application gives a } \\
\text { clear description. }\end{array}$ & 4.19 & 0.80 \\
\hline 6. & $\begin{array}{l}\text { The icons and buttons used are } \\
\text { appropriate. }\end{array}$ & 4.11 & 0.76 \\
\hline 7. & $\begin{array}{l}\text { Application exit icon makes it } \\
\text { easy for students to exit this } \\
\text { Iedutech application. }\end{array}$ & 4.23 & 0.71 \\
\hline 8. & $\begin{array}{l}\text { The use of colors in this } \\
\text { android application is very } \\
\text { good to see. }\end{array}$ & 4.23 & 0.76 \\
\hline 9. & $\begin{array}{l}\text { I can easily get the information } \\
\text { i need. }\end{array}$ & 4.15 & 0.83 \\
\hline
\end{tabular}

\begin{tabular}{|c|l|c|c|}
\hline 10. & $\begin{array}{l}\text { No technical interruptions } \\
\text { occurred while using this } \\
\text { software. }\end{array}$ & 4.11 & 0.81 \\
\hline \multicolumn{2}{|c|}{ Total Average } & $\mathbf{4 . 1 7}$ & 0.67 \\
\hline
\end{tabular}

\subsection{Interface Design Analysis}

In the interface design evaluation, there were ten (10) different questions that the respondents had to answer and this section focused on key elements such as background, windows and panels, buttons and icons, text, graphics, audio, video, animation and so on. The results obtained (mean = $4.24, \mathrm{sd}=0.65$ ) indicate respondents with the design provided in the Iedutech mobile application. One was the item (mean = $4.34, \mathrm{sd}=0.74$ ) "the colors used in this Iedutech application caught my attention". This is supported [20] color choices also needed interesting effects such as Information Visualization Theory. Therefore, the interface developed must be in accordance with the principles of design of the interface specified [21].

Table 5: Interface Design Analysis of Users

\begin{tabular}{|c|l|c|c|}
\hline No. & \multicolumn{1}{|c|}{ Details } & Mean & $\begin{array}{c}\text { Std. } \\
\text { Deviation }\end{array}$ \\
\hline 1. & $\begin{array}{l}\text { I can control the speed of the } \\
\text { content presentation in this } \\
\text { Iedutech application. }\end{array}$ & 4.26 & 0.72 \\
\hline 2. & $\begin{array}{l}\text { The presentation of the content } \\
\text { in this Iedutech application is } \\
\text { subject to topic. }\end{array}$ & 4.19 & 0.69 \\
\hline 3. & $\begin{array}{l}\text { This Iedutech application is } \\
\text { divided into other related } \\
\text { sections. }\end{array}$ & 4.23 & 0.76 \\
\hline 4. & $\begin{array}{l}\text { The content of the lessons is } \\
\text { easy to follow. }\end{array}$ & 4.23 & 0.76 \\
\hline 5. & $\begin{array}{l}\text { The menu view of this } \\
\text { Iedutech application gives a } \\
\text { clear description. }\end{array}$ & 4.34 & 0.74 \\
\hline 6. & $\begin{array}{l}\text { The icons and buttons used are } \\
\text { appropriate. }\end{array}$ & 4.15 & 0.78 \\
\hline 7. & $\begin{array}{l}\text { Application exit icon makes it } \\
\text { easy for students to exit this } \\
\text { Iedutech application. }\end{array}$ & 4.26 & 0.82 \\
\hline 8. & $\begin{array}{l}\text { The use of colors in this } \\
\text { android application is very } \\
\text { good to see. }\end{array}$ & 4.15 & 0.83 \\
\hline 9. & $\begin{array}{l}\text { I can easily get the information } \\
\text { i need. }\end{array}$ & 4.30 & 0.73 \\
\hline 10. & $\begin{array}{l}\text { No technical interruptions } \\
\text { occurred while using this } \\
\text { software. }\end{array}$ & 4.26 & $\mathbf{4 . 2 4}$ \\
\hline & \multicolumn{1}{|c|}{ Total Average } \\
\hline
\end{tabular}




\section{CONCLUSION}

In conclusion, the results showed that respondents agreed that the Iedutech application for Information Technology in Education subjects created more effective and entertaining T\&L process. In terms of performance, multimedia elements are very important in a software as it enhances user interest and attention [22]. In addition, the development of this software will be impetus for the production of more and more android-based application software in the future to solve the problem of interactive software. Plus, [23] states mobile application provides convenience for users without spending time and money and they can also access it anywhere.

\section{ACKNOWLEDGEMENT}

The authors would like to thank the Ministry of Higher Education, Malaysia, for supporting this research under the Research fund, E15501, Research Management Centre, UTHM and Geran Penyelidikan Pasca Siswazah (GPPS) VOT No H440. In addition, the authors also wish to thank the students of Universiti Tun Hussein Onn Malaysia, Batu Pahat who had given their full cooperation to ensure the success of this study.

\section{REFERENCES}

1. Harlina binti Ishak, Zubaidah Mat Nor \& Ainee Ahmad (2017). Pembelajaran Interaktif Berasaskan Aplikasi Kahoot dalam Pengajaran Abad Ke-21. Buku Panduan Pelaksanaan Pendidikan Abad ke21. Institut Pendidikan Aminuddin Baki, Kementerian Pendidikan Malaysia.

2. Abd Rahman Abd Aziz. (2009). Mengurus Tingkah laku Pelajar. PTS Profesional.

3. Rafiza Abdul Razak, \& Siti Zarina Syed Nordin. (2013). Projek Pembangunan Perisian Multimedia: Strategi Pengajaran Yang Membentuk Keperibadian Guru Pelatih. Jurnal Kurikulum Dan Pengajaran Asia Pasifik, 1(1), 42-52

4. Traxler, J. (2017). Defining, Discussing and evaluating mobile learning: the moving writes and having writ. International Review of Research in Open and Distance Learning, 8(2): 1492-3831.

http://www.irrodl.org/index.php/irrodl/article/view/346 /875

https://doi.org/10.19173/irrodl.v8i2.346

5. Ahmad Sobri Shuib. (2010). Reka bentuk kurikulum M-Pembelajaran Sekolah Menengah: Teknik Delphi. Proceedings of Regional Conference on Knowledge Integration in Information and Communication Technology 2010, pp. 652-665

6. Mohd Paris Bin Saleh (2016). Model Pengajaran M-Pembelajaran Berasaskan Kaedah Inkuiri Mata
Pelajaran Sejarah Peringkat Menengah. Fakulti Pendidikan Universiti Malaya Kuala Lumpur.

7. Anuar Ahmad dan Nelson Jinggan, 2015. Pengaruh Kompetensi Kemahiran Guru Dalam Pengajaran Terhadap Pencapaian Akademik Pelajar Dalam Mata Pelajaran Sejarah. Bil. 3 Isu 2.

8. Georgiev, Tsvetozar, dkk. 2004. M-Learning - a New Stage of E-Learning (Online), disampaikan dalam International Conference on Computer Systems and Technologies, (http://ecet.ecs.ru.acad.bg/cst04/docs/siv/428.pdf, diakses pada 30 Desember 2012) https://doi.org/10.1145/1050330.1050437

9. Teodorescu, Adriana. 2015. Mobile Learning and It's Impact in Business English Learning. Elsevier Ltd. https://doi.org/10.1016/j.sbspro.2015.02.303

10. Thitiporn \& Sittichailapa, dkk. 2015. The Development of Model Learning Media of Sorting Algorithm. Elsevier Ltd. https://doi.org/10.1016/j.sbspro.2015.07.333

11. Adam, A., Abdul Razak, S. \& Abu Bakar, M. H. (2011). Kecenderungan Pelajar-Pelajar Semester Akhir Kolej Komuniti Jasin Terhadap Keusahawanan. Mini Seminar Pendidikan Kolej Komuniti Jasin

12. Jamalludian Harun dan Zaidatun Tasir. (2003). Multimedia dalam pendidikan. Pahang: PTS Publications \& Distributors Sdn. Bhd

13. Baharuddin Aris, Rio Sumarni Shariffudin, Manimegalai Subramaniam. (2002). Rekabentuk Perisian Multimedia. Skudai, Johor: UTM.

14. SJ McGriff. (2003). Instructional system design (ISD): Using the ADDIE model. Retrieved June 10 (2003), 513-553

15. Aminuddin Hassan, Fadzilah Abd Rahman \& Sim Kuan Yew. (2015). Meneroka Pemikiran Logik Melalui Penggunaan Aplikasi Mudah Alih. 1International Journal of Education and Training (InjET)1(2) November: 1-7 (2015)International Journal of Education and Training (InjET)1(2)November: 1-7(2015).

16. Sezen, N. and Bülbül A. (2011) A Scale of Logical Thinking. Procedia Social and Behavioral Sciences 15 (2011) 2476-2480 https://doi.org/10.1016/j.sbspro.2011.04.131

17. Latifah Abdul Majid, Wan Nasyrudin Wan Abdullah, \& Nurul Hidayah Ahmad Zakhi. (2012). Penerapan nilai murni dan pembentukan jati diri kanak-kanak prasekolah melalui penggunaan multimedia. Journal Hadhari Special Edition, 51-56.

18. Ibrahim, M. A., Ashaari, N. S. @, \& Wook, T. S. M. T. (2013). Colour Impressions Framework. Procedia Technology, 11(Iceei), 305-311. doi:10.1016/ j.protcy.2013.12.195

19. Deubel, P. (2003). An investigation of behaviourist and 
cognitive approaches to instructional multimedia design. Journal of Educational multimedia and hypermedia, 12(1), 63-90.

20. Norasikin, F., Zawawi, I., Shahrul Azman M. A., Zarina, S., \& Juhana, S. (2011). Aplikasi reka bentuk system visualisasi maklumat berasaskan teori persepsi visual dalam ilmu hadis. Journal of Islamic and Arabic Education, 3(1), 1-12. Retrieved from http://journalarticle.ukm.my/2196/1/21_0.pdf

21. Norfadilah K. (2010). Challenges of Malaysian developers in creating good interfaces for interactive courseware. Turkish online journal of educational technology, 9(1), 37-42.

22. Wan Hassan, W.A.S., Ariffin, A., Ahmad, F., Mohamad, N. \& Anuar, R. "SolveMe" Website Development using Problem-based Learning Approach in Technical and Vocational Education. International Journal of Advanced Trends in Computer Science and Engineering, 9(2), March - April 2020, 2173 - 2177. https://doi.org/10.30534/ijatcse/2020/193922020

23. Wan Hassan, W.A.S., Rosli, D.I., Ariffin, A., Ahmad, F., Jamin, J. The Application of Bonang Gamelan Music Based on Mobile Application. International Journal of Recent Technology and Engineering (IJRTE). ISSN: 2277-3878, Volume-8 Issue-6, March 2020.

https://doi.org/10.35940/ijrte.F7554.038620 